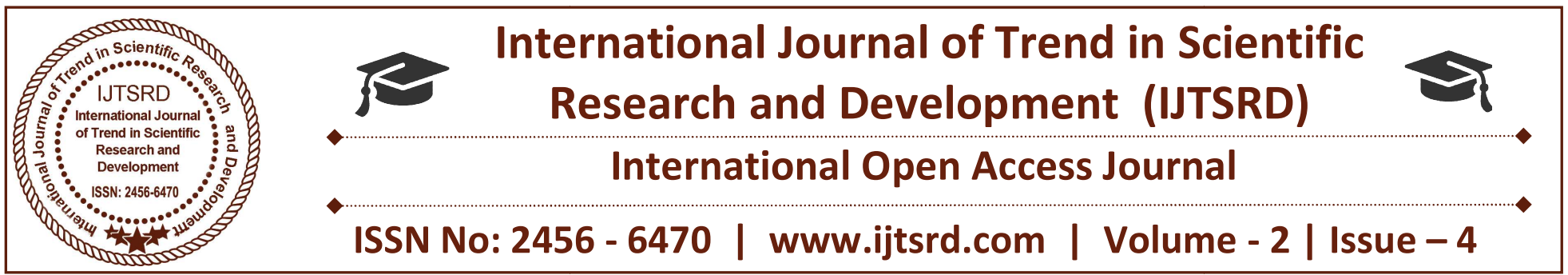

\title{
The Suture Line: Himalayan Belt
}

\author{
Biplab Tripathy \\ Assistant Professor, Arunachal University of Studies \\ Namsai, Arunachal Pradesh, India
}

\begin{abstract}
Suture is very common term used to explain the plate boundary in geography and geology. The term suture is a medical term but geographically it refers to the area of convergent plate margin. Area is very important for the study of tectonic landforms. The Himalayan belt is a great example of suiter line lies between Eurasian and Indian plate. It is longest suture in the theory of plate-tectonic. The suture is very sensitive for its destructive nature. Orogenesis process made the region very differ from other. Various natural disasters are happened on suture. Nepal earth quake is a very recent devastating phenomenon on Indo-Eurasian suture.
\end{abstract}

Keywords: Suture line, Plate boundary, Convergent plate boundary, Tectonic Landform. Indo-Eurasian Suture

\section{INTRODUCTION}

The term "Suture" means the line between two bones. The term is related with medical science. It is firstly used by Soviet paleontologists Schindewolf in the year 1963. In the field of geography and geology the term is generally used to show the area of subduction. The term subduction means, the area where two convergent plates moved face to face and heavy plate moves under another lighter plate and in some cases sinks into the mantle. The region of subduction is called subduction zone or Benioff zone.

The suture line is the outer line on the surface of the earth. It is a fault line between two plates. The width of suture may vary from few kilometers to few hundred kilometers.

In the theory of plate tectonics suture line is very important to study the nature of convergent plate margin. The detail study on subduction also depends on the surface structure of suture. Various landforms are found on suture as like fold, faults, volcanic mountain, folded mountain etc. Due to its vertical location on subduction the suture line is highly earthquake prone.

The best example of suture is Himalayan belt, which is located between Indian and Eurasian plate. The suture will be active if the plates are active. There are two types of suture line found-1.Active suture, 2.Inactive suture. But maximum sutures are active, inactive suture is very rare.

When plate boundary becomes active, there various destructive activities are started on suture line. Due to long time collision the rocks of this region become change into metamorphic. According to Dewey (1977) "Suture line is very simple and a collision line between two plates".

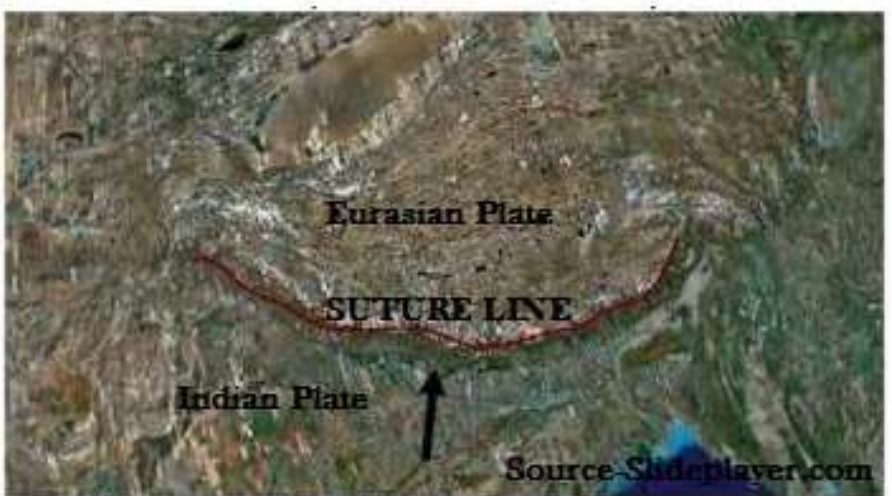

Fig-The suture line between Indian and Eurasian plate 


\section{STRUCTURE OF SUTURE LINE}

Suture is the line located at the frontal part of two plates. When one plate is subducted with another, there geosyncline occurred. Geosyncline is a first step of collision. It is also the first step of folded mountain formation. On the surface of the earth suture zone is only the representative of such area beneath which subduction zone are located. Actual line of suture is identified by belt of earth quake and chain of folded mountain with highest peak. Various types of fold and fault as like anticline, syncline, Overturned fold, recumbent fold trust fault, reverse fault etc. are found here. The force, which is related with the landform process on the suture area, is called orogenesis and epeirogenesis. Intrusive landforms are mostly found here as like batholiths, laccoliths, facoliths, etc.

\section{TYPES OF SUTURE}

Suture may be classified on the basis of its nature and size and area. According to the size of suture it may divide into three categories as likel.Macro Suture, 2.Meso suture 3.Micro suture. The length of the suture is decided by plate size. After convergent movement of two major plates, macro suture formed. Indo- Eurasian suture or Asiatic suture is an example of Macro suture similarly meso and micro suture is formed by convergent movement of meso and micro plate.

\section{CHARACTERISTICS OF SUTURE}

1. It is the boundary line between two plates

2. The line is just vertical surface from subduction

3. Huge no of fold and faults are found here

4. Metamorphism of rock is very common in this area

5. The area is very highly earth quake prone

6. Volcanic activities are very common here

\section{INDO-EURASIAN SUTURE (THE HIMALAYAN BELT)}

Great Himalaya is a $2900 \mathrm{Km}$ longest representative of suture line located between India and Eurasia. According to the theory of continental drift of Wegner, about 140 million years ago there was a super mass of land which called Pangaea and surrounding water body is called Panthalassa, after the break of continent Pangaea divided into various plates and separated from each other.The region is formed before 40 to 50 million years ago, when two major plate India and Eurasia driven by plate movement and collided with each other. Indian North West to north east large ' $U$ ' shaped margin is very active and youngest one in the world. The line is passes through the countries of India, Nepal and china, Bhutan and Myanmar. This suture was formed at Cainozoic Era. That is why it is called Cainozoic suture and according to its location it is called Asiatic suture. The Indian plate moving towards the north related to the Eurasian plate and the collision creates subduction at the interior earth. Recent study shows that presently the average speed of Indian plate is almost $5 \mathrm{~cm}$ per year. These movements are the main cause of frequent earth quake in this area. The suture line longitudinally divided into five zones, these are Kashmir, Punjab, Kumaon, Central,Assam Himalaya.

The suture between India and Tibetan Plateau is called Asiatic Suture it is extended up to north eastcorner of India but actually extended up to Australian plate, that's why in some cases the portion between Indian and Australian plate is called the Indo-Australian plate. The line of suture on these two plates is a result of subduction. It is divided into lots intercontinental micro suture. These sutures are found by fault lines, chain of mountain on the earth. The satellite view of this region provides a chronological order of height from center to margin. Marin of suture is lightly folded than its middle portion. The highest peak of Himalaya is located at the middle chain of Suture.

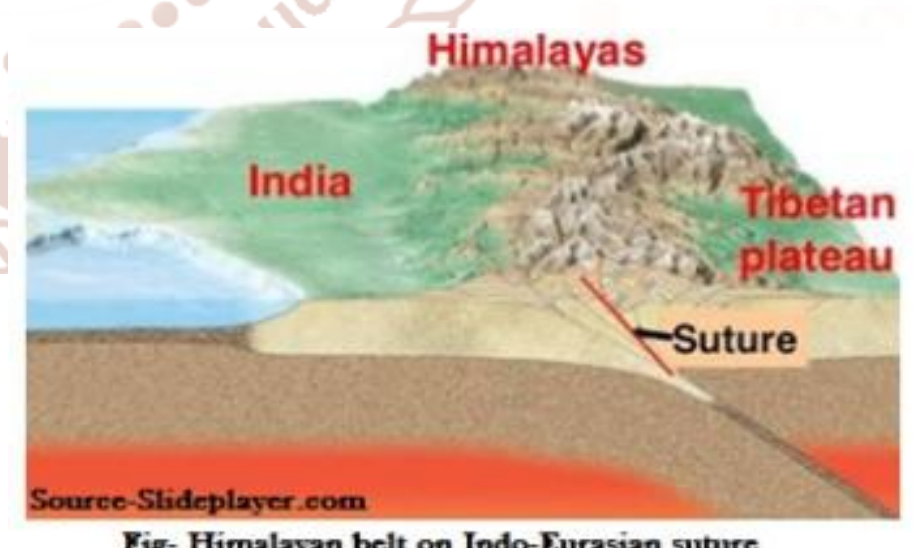

\section{SUTURE LINE ACTIVITIES}

The suture line is very sensitive belt of earth. Amy time and any moment it may be destructive in nature. Due to such characters, it is most disaster prone. Various endogenetic disasters as like earth quake, 
landslide, volcanic eruption etc. are frequently REFERENCES

happened in the suture zone.

Indo-Eurasian suture is a cause of many devastating earthquakesin India and surrounding countries those are located nearest in suture. April 2015 Nepal earthquake is one of the example of disaster on suture line. According to the USGS report it was happened due to movement of Indian Plate toward underneath the Eurasian Plate. These suture line pusses through the Nepal and Lamjung in Nepal was the epicenter of earth quake.

1) Ahir, Rajiv, 2013: Spectrum's Geography, Spectrum Books Pvt. Ltd. New Delhi

2) Wikipedia, 2/7/2017: Suture, (Geology),http://en.m.wikipedia.org/wiki/suture_ geology

3) Dewey, John, 1977: Tectonophysics, Vol-40, Issue-1-2, $8^{\text {th }}$ June 1977, (P-53-67)

4) The Himalayas: Two continentals collide (http://pubs.usgs.gov/publication/text/himalaya.ht $\mathrm{ml})$

5) M 7.8-36Km, E of Khudi, Nepal, 25/04/2015, United State Geological Survey

6) International Geology Review, Ammonoid suture line terminology, Vol 7, 1965- Issue 10.

7) Vivo Benedetto, Grasemann Bernhard, Stuwe Kurt, 2009: Geology-Vol IV, EOLSS Publication.

8) Busch, Jay \&Mezger, Klaus \&Pluijim, Ben, 'Suturing and extensional reactivation in the Grenville orogeny, Canada' Geology, June 1997, $\mathrm{V}-25$ 